\title{
FOURTEENTH ANNUAL LIST OF PAPERS
}

\section{READ BEFORE THE AMERICAN MATHEMATICAL SOCIETY AND SUBSEQUENTLY PUBLISHED, INCLUDING REFERENCES TO THE PLACES OF THEIR PUBLICATION.}

Allandice, R. E. On a Linear Transformation, and some Systems of Hypocycloids. Read May 3, 1902. Annals of Mathematics, ser. 2, vol. 5, No. 4, pp. 169-172; July, 1904.

BirkноғF, G. D. and Vandiver, H. S. On the Integral Divisors of $a^{n}-b^{n}$. Read Dec. 29, 1902, Annals of Mathematics, ser. 2, vol. 5, No. 4, pp. 173-180; July, 1904.

Buichfeldt, H. F. On the Order of Linear Homogeneous Groups (Second Paper). Read (San Francisco) Dec. 25, 1903. Transactions of the American Mathematical Society, vol. 5, No. 3, pp. 310-325 ; July, 1904.

A Theorem Concerning the Invariants of Linear Homogeneous Groups, with some Applications to Substitution Groups. Read (San Francisco) Apr. 30, 1904. Transactions of the American Mathematical Society, vol. 5, No. 4, pp. 461-466 ; Oct., 1904.

The Finite Discontinuous Primitive Groups of Collineations in Four Variables. Read (San Francisco) Apr. 30, 1904. Mathematische Annalen, vol. 60, No. 2, pp. 204-231 ; Mar., 1905.

- On Imprimitive Linear Homogeneous Groups. Read (San Francisco) Feb. 25, 1905. Transactions of the American Mathematical Society, vol. 6, No. 2, pp. 230-236 ; April, 1905.

Buiss, G. A. The Exterior and Interior of a Plane Curve. Read (Chicago) Apr. 2, 1904. Bulletin of the American Mathematical Society, ser. 2, vol. 10, No. 8, pp. 398-404; May, 1904.

- Sufficient Condition for a Minimum with respect to One-Sided Variations. Read (Chicago) Apr. 2, 1904. Transactions of the American Mathematical Society, vol. 5, No. 4, pp. 477-492 ; Oct., 1904.

Bôcher, Maxime. A Problem in Statics and its Relation to Certain Algebraic Invariants. Read Apr. 30, 1904. Proceedings of the American Academy of Arts and Sciences, vol. 40. No. 11, pp. 469-484; Dec., 1904.

Bolza, Oskar. Lectures on the Calculus of Variations. Read Aug. 21-24, 1901. Decennial. Publications of the University of Chicago, ser. 2, vol. 14; 1904.

Bouton, C. L. Note on Isothermal Curves and One-Parameter Groups of Conformal Transformations in the Plane. Read Feb. 25, 1905. Bulletin of the American Mathematical Society, vol. 11, No. 7, pp. 369-371; April, 1905.

Brows, E. W. On the Completion of the Solution of the Main Problem in the New Lunar Theory. Read Oct. 29, 1904. Monthly Notices of the Royal Astronomical Society, vol. 65, No. 2, pp. 104-108; Dec., 1904.

On the Smaller Perturbations of the Lunar Arguments. Read Feb. 27, 1904. Transactions of the American Mathematical Society, vol. 5, No. 3, pp. 279-287; July, 1904. 
CAmpbeli, D. F. On Homogenous Quadratic Relations in the Solutions of a Linear Differential Equation of the Fourth Order. Read (Chicago) Jan. 2, 1903. Quarterly Journal of Pure and Applied Mathematics, vol. 36, No. 4, pp. 296-304; May, 1905.

Chessin, A. S. On a Class of Differential Equations. Read Sept. 1, 1903. American Journal of Mathematics, vol. 27, No. 2, pp. 103-112 ; Apr., 1905.

- On the Strains in a Rapidly Rotating Disc. Read (Chicago) Apr. 11, 1903. Transactions of Academy of Science of St. Louis, vol. 13, No. 1, pp. xxxii-xxxvi; Nov., 1903.

Collins, J. V. Sorne Developments in Vector Analysis. Read (Chicago) Dec. 31, 1903. Jahresbericht der Deutschen Mathematiker-Vereinigung, vol. 14, Nos. 3-4, pp. 164-167; Mar.-Apr., 1905; and American Mathematical Monthly, vol. 12, No. 2, pp. 38-41; Feb., 1905.

Dickson, L. E. A New System of Simple Groups. Read Sept. 2, 1902, Mathematische Annalen, vol. 60, No. 1, pp. 137-150; Jan., 1905.

- Memoir on Abelian Transformations. Read (Chicago) Jan. 1, 1904. American Journal of Mathematics, vol. 26, No. 3, pp. 243-317 ; July, 1904.

- Application of Groups to a Complex Problem in Arrangements. Read (Chicago) Apr. 2, 1904. Annals of Mathematics, ser. 2, vol. 6, No. 1, pp. 31-44; Oct., 1904.

- The Group of a Tactical Configuration. Read Dec. 29, 1904. Bulletin of the American Mathematical Society, vol. 11, No. 4, pp. 177-179; Jan., 1905.

A General Theorem on Algebraic Numbers. Read Dec. 29, 1904. Bulletin of the American Mathematical Society, vol. 11, No. 9, pp. 482-486; June, 1905.

Definitions of a Group and a Field by Independent Postulates. Read (Chicago) Dec. 30, 1904. Transactions of the American Mathematical Society, vol. 6, No. 2, pp. 198-204; Apr., 1905.

- On Semi-Groups and the General Isomorphism between Infinite Groups. Read (Chicago) Dec. 30, 1904. Transactions of the American Mathematical Society, vol. 6. No. 2, pp. 205-208; A pr., 1905.

- Determination of the Ternary Modular Groups. Read (Chicago) Dec. 30, 1904. American Journal of Mathematics, vol. 27, No. 2, pp. 189-202; Apr., 1905.

— The Minimum Degree $\tau$ of Resolvents for the $p$-Section of the Periods of Hyperelliptic Functions of Four Periods. Read (Chicago) Dec. 30, 1904. Transactions of the American Mathematical Society, vol. 6, No. 1, pp. 48-57 ; Jan., 1905.

- On the Cyclotomic Function. Read (Chicago) Apr. 22, 1905. American Mathematical Monthly, vol. 12, No. 4, pp. 86-89; Apr. 1905.

- Determination of all the Subgroups of Orders the Three Highest Powers of $p$-in the Group $G$ of all $m$-ary Linear Homogeneous 'Transformations Modulo p. Read Sept. 17, 1904. Quarterly. Journal of Pure and Applied Mathematrcs, vol. 36, No. 4, pp. 373-384; May, 1905.

- On the Class of the Substitutions of Various Linear Groups. Read Apr. 29, 1905. Bulletin of the American Mathematical Society, vol. 11, No. 8, pp. 426-432; May, 1905. 
Dowling, L. W. On the Conformal Representation of Certain Isosceles Triangles upon the Upper Half Plane. Read (Chicago) Jan. 2, 1902. Annals of Mathematics, ser. 2, vol. 6, No. 2, pp. 69-85; Jan., 1905.

EDDy, H. T. On the Complex Product of Electromotive Force, Current and Other Vectors. Read Aug. 31, 1903. Electrical World and Engineer, vol. 44, No. 4, pp. 133-135; July $23,1904$.

EISENHART, L. P. Surfaces with the same Spherical Representation of their Lines of Curvature as Pseudospherical Surfaces. Read Oct. 31, 1903. American Journal of Mathematics, vol. 27, No. 2, pp. 113-172, Apr., 1905.

Three Particular Systems of Lines on a Surface. Read Feb. 27, 1904. Transactions of the American Mathematical Society, vol. 5, No. 4, pp. 421437 ; Oct., 1904.

- On the Deformation of Surfaces of Translation. Read Feb. 25, 1905. Bulletin of the American Mathematical Society, vol. 11, No. 9, pp. 486-494; June, 1905.

Emch, A. On the Involution of Stresses in a Plane. Read (Chicago) Jan. 3, 1903. Author's introduction to Projective Geometry, pp. 223-239; Jan., 1905.

Epsteen, Saul, and Maciagan-Wedderburn, J. On the Structure of Hypercomplex Number Systems. Read (Chicago) Dec. 30, 1904. Transactions of the American Mathematical Society, vol. 6, No. 2, pp. 172178 ; Apr., 1905.

Findlay, William. The Sylow Subgroups of the Symmetric Group. Read Feb. 27, 1904. Transactions of the American Mathematical Society, vol. 5, No. 3, pp. 263-278; July, 1904.

Fiske, T. S. Presidential Address: Mathematical Progress in America. Read Dec. 29, 1904 . Science, New Series, vol. 21, No. 528, pp. 209-215; Feb. 10, 1905; and Bulletin of the American Mathematical Society, vol. 11, No. 5, pp. 238-246 ; Feb., 1905.

Ford, W. B. Sur la Fonction définie par une Série de Maclaurin. Read Dec. 29, 1903. Journal de Mathématiques, ser. 5, vol. 9, No. 2, pp. 22 3232 ; June, 1903.

Fréchet, Maurice. Sur les Opérations linéaires. Read Sept. 17, 1904. Transactions of American Mathematical Society, vol. 5, No. 4, pp. 493-499; Oct., 1904.

— Sur les Opérations linéaires (deuxième Note). Read Dec. 29, 1904. Transactions of the American Mathematical Society, vol. 6, No. 2, pp. 134140 ; Apr., 1905.

HANCOCK, H. Remarks on the Sufficient Conditions in the Calculus of Variations. Read Dec. 29, 1902. University of Cincinnati Bulletin of Mathematics, No. 1, pp. 203-204; 1904.

Haskeld, M. W. The Construction of Conics under Given Conditions. Read (San Francisco) Apr. 30, 1904. Bulletin of the American Mathematical Society, vol. 11, No. 5, pp. 268-273; Feb., 1905.

Hawkes, H. E. On Hypercomplex Number Systems in Seven Units. Read Apr. 25, 1903. American Journal of Mathematics, vol. 26, No. 3, pp. 223-242; July, 1904.

- On Quaternion Number Systems. Read Feb. 27, 1904. Mathematische Annalen, vol. 60 , No. 3, pp. 437-447; May, 1905 . 
Hiltebeitel, A. M. Note on a Problem in Mechanics. Read Feb. 25, 1905. Bulletin of the American Mathematical Society, vol. 11, No. 8, pp. 432-436 ; May, 1905.

Huntington, E. V. Sets of Independent Postulates for the Algebra of Logic. Read Sept. 1, 1903, Dec. 28, 1903, and Apr. 30, 1904. Transactions of the American Mathematical Society, vol. 5, No. 3, pp. 288-309; July, 1904.

A Set of Postulates for Real Algebra, comprising Postulates for a OneDimensional Continuum and for the Theory of Groups. Read Sept. 17, 1904. Transactions of the American Mathematical Society, vol. 6, No. 1, pp. 17-41; Jan., 1905.

- Note on the Definitions of Abstract Groups and Fields by Sets of Independent Postulates. Read Dec. 30, 1904. Transactions of the American Mathematical Society, vol. 6, No. 2, pp. 181-197 ; Apr., 1905.

- A Set of Postulates for Ordinary Complex Algebra. Read Dec. 30, 1904. Transactions of the American Mathematical Society, vol. 6, No. 2, pp. 209-229; Apr., 1905.

Hutchinson, J. I. On the Automorphic Functions of the Group $(0,3$; 2, 6, 6). Read Aug. 31, 1903, and Dec. 28, 1903. Transactions of the American Mathematical Socipty, vol. 5, No. 4, pp. 447-460 ; Oct., 1904.

Kasner, E. Surfaces whose Geodesics may be Represented in the Plane by Parabolas. Read Dec. 30, 1902. Transactions of the American Mathematical Society, vol. 6, No. 2, pp. 141-158 ; A pr., 1905.

- A Characteristic Property of Isothermal Systems of Curves. Read Dec. 29, 1903. Mathematische Annalen, vol. 59, No. 3, pp. 352-354 ; Oct., 1904.

- Galileo and the Modern Concept of Infinity. Read Feb. 27, 1904. Bulletin of the American Mathematical Society, vol. 11, No. 9, pp. 499-501; June, 1905.

LeHmer, D. N. On a Cylinder the Intersection of which with a Sphere will Develop into an Ellipse. Read (San Francisco) Apr. 30, 1904. American Mathematical Monthly, vol. 11, No. 10, pp. 186-187 ; Oct., 1904.

Lovert, E. O. Singular Trajectories in the Restricted Problem of Four Bodies. Read Apr. 30, 1904. Annali di Matematica pura ed applicata, ser. 3, vol. 11, No. 1, pp. 1-8; Nov., 1904.

Macaulay, F. S. On a Method of Dealing with the Intersections of Plane Curves. Read Sept. 17, 1905. Transactions of the American Mathematical Society, vol. 5, No. 4, pp. 385-410; Oct., 1904.

Maclagan-Wedderburn, J. See Epsteen, S.

Manning, W. A. On the Primitive Groups of Class $3 p$. Read (San Francisco) Apr. 25, 1903. Transactions of the American Mathematical Society, vol. 6, No. 1, pp. 42-47; Jan., 1905.

Mason, Max. Sur les Solutions satisfaisant à des Conditions aux Limites données de l'Équation differentielle $\Delta u+\lambda \mathrm{A}(x, y) u=f(x, y)$. Read Feb. 27, 1904, and Oct. 29, 1904 . Journal de Mathématiques, ser. 5, vol. 10, No. 4, pp. 445-476 ; Dec., 1904.

- The Doubly Periodic Solutions of Poisson's Equation in two Independent Variables. Read Dec. 29, 1904. Transactions of the American Mathematical Society, vol. 6, No. 2, pp. 159-164; Apr., 1905. 
Millfer, G. A. On the Number of Sets of Conjugate Subgroups. Read Oct. 31, 1903. Prace Matematyczno-Fizyczne, vol. 15, pp. 87-90; 1904.

On the Roots of the Operators of a Group. Read (San Francisco) Dec. 19, 1903. Quarterly Journal of Pure and Applied Mathematics, vol. 36, No. 1, pp. 51-55 ; Sept., 1904.

Addition to a Theorem due to Frobenius. Read (San Francisco) Apr. 30, 1904. Bulletin of the American Mathematical Society, vol. 11, No. 1, pp. $6-7$; Oct., 1904.

- Note on Burnside's Theory of Groups. Read Sept. 17, $1904 . \quad$ Bulletin of the American Mathematical Society, vol. 11, No. 2, p. 64, $z 14$; Nov., 1904.

Groups of the Fundamental Operations of Arithmetic. Read Oct. 29, 1904. Annals of Mathematics, ser. 2, vol. 6, No. 3, pp. 41*-48*; Apr., 1905.

Determination of all the Groups of Order $2^{m}$ which Contain an odd Number of Cyclic Subgroups of Composite Order. Read (San Francisco) Oct. 1, 1904. Transactions of the American Mathematical Suciety, vol. 6, No. 1, pp. 58-62; Jan., 1905.

Moore, E. H. On a Definition of Abstract Groups. Read Dec. 30, 1904. Transactions of the American Mathematical Society, vol. 6, No. 2, pp. 179180 ; Apr., 1905.

Moremead, J. C. Note on a Theorem of Lucas on Fermat's Numbers. Read Oct. 29, 1904. Bulletin of the American Mathematical Society, vol. 11, No. 3, p. 114, \& 5 ; Dec., 1904.

— Note on Fermat's Numbers. Read Apr. 29, 1905. Bulletin of the American Mathematical Scciety, vol. 11, No. 10, pp. 543-545; July, 1905.

Morley, F. On the Geometry whose Element is the 3-Point of a Plane. Read Aug. 31, 1903 and Dec. 29, 1903. Transactions of the American Mathematical Society, vol. 5, No. 4, pp. 467-476 ; Oct., 1904.

Morrison, Mrs. [GRow, B. E.] Removal of Any Two Terms from a Binary Quantic by Linear Transformations. Read June 27, 1900. American Journal of Mathematics, vol. 23, No. 3, pp. 2ð7-296; July, 1901.

Moritz, R. E. A General Theorem on Local Probability. Read (San Francisco) Feb. 25, 1905. American Mathematical Monthly, vol. 12, No. 3, pp. 59-64; Mar., 1905.

Peirce, J. M. On Certain Complete Systems of Quaternion Expressions, and on the Removal of Metric Limitations from the Calculus of Quaternions. Read Apr. 30, 1904. Transactions of the American Mathematical Society, vol. 5, No. 4, pp. 411-420; Oct., 1904.

Rietz, H. L. On Groups in which certain Commutative Operations are Conjugate. Read (Chicago) Dec. 31, $1903 . \quad$ Transactions of the American Mathematical Society, vol. 5, No. 4, pp. 500-508; Oct., 1904.

Simply Transitive Primitive Groups which are Simple Groups. Read (Chicago) Apr. 22, 1905. Bulletin of the American Mathematical Society, vol. 11, No. 10, pp. 545-546 ; July, 1905.

Ros, E. D. JR. On the Coefficients in the Quotient of two Alternants. Read Dec. 29, 1902. Transactions of the American Mathematical Society, vol. 6, No. 1, pp. 63-74; Jan., 1905. 
Rusk, W. J. Note on the $n$th Derivative of a Determinant whose Constituents are Functions of a given Variable. Read (Chicago) Apr. 2, 1904. American Mathematical Monthly, vol. 12, No. 4, p. 85 ; Apr. 1905.

Shaw, J. B. Algebras Defined by Finite Groups. Read (Chicago) Dec. 31, 1903. Transactions of the American Mathematical Society, vol. 5, No. 3, pp. 326-342; July, 1904.

Slocum, S. E. The Strength of Flat Plates, with an Application to Concrete Steel Floor Panels. Read (Chicago) Apr. 2, 1904. Engineering News, vol. 52, No. 1, pp. 22-24; July 7, 1904.

Relation between Real and Complex Groups with Respect to their Structure and Continuity. Read (Chicago) Jan. 3, 1903. American Journal of Mathematics, vol. 27, No. 1, pp. 7-14 ; Jan., 1905.

Smith, Burke. On the Deformation of Surfaces of Translation. Read Dec. 29, 1904. Bulletin of the American Mathematical Society, vol. 11, No. 4, pp. 187-191; Jan., 1905.

Smith, P. F. On the Linear Transformations of a Quadratic Form into Itself. Read Dec. 28, 1901, and Dec. 29, 1903. Transactions of the American Mathematical Society, vol. 6, No. 1, pp. 1-16 ; Jan., 1905.

SNyder, VIRtir. On the Forms of Sextic Scrolls having a Rectilinear Directrix. Read Dec. 28, 1903. American Journal of Mathematics, vol. 27, No. 1, pp. 77-102; Jan., 1905.

- On Developable and Tubular Surfaces having Spherical Lines of Curvature. Read Apr. 30, 1904. Bulletin of the American Mathematical Society, vol. 11, No. 1, pp. 1-6; Oct., 1904.

- On the Quintic Scroll having a Tacnodal or Oscnodal Conic. Read Oct. 29, 1904. Bulletin of the American Mathematical Society, vol. 11, No. 4, pp. 182-186 ; Jan., 1905.

- On the Forms of Sextic Scrolls having no Rectilinear Directrix. Read Dec. 29, 1904. American Journal of Mathematics, vol. 27, No. 2, pp. 173188 ; Apr., 1905.

Stringham, Irving. A Geometric Construction for Quaternion Products. Read (San Francisco) Feb. 25, 1905. Bulletin of the American Mathematical Society, vol. 11, No. 8, pp. 437-439; May, 1905.

Taber, Henry. On Hypercomplex Number Systems. Read Feb. 27, 1904. Transact'ons of the American Mathematical Society, vol. 5, No. 4, pp. 509-548; Oct., 1904.

VAndiver, H. S. See BirkhofF, G. D.

VAN Vleck, E. B. On the Convergence of Algebraic Continued Fractions whose Coefficients have Limiting Values. Read Feb. 27, 1904. Transactions of the American Mathematical Society, vol. 5, No. 3, pp. 253-262 ; July, 1904.

Selected Topics in the Theory of Divergent Series and of Continued Fractions. Read Sept. 2-5, 1903. The Boston Colloquium Lectures on Mathematics, pp. 75-187; 1905.

Veblen, Oswald, A Set of Axioms for Geometry. Read (Chicago) Apr. 11, 1903. Transactions of the American Mathematical Society, vol. 5, No. 3, pp. 343-384: July, 1904. 
Theory of Plane Curves in Non-Metrical Analysis Situs. Read Sept. 17, 1904. Transactions of the American Mathematical Society, vol. 6, No. 1, pp. 83-98; Jan., 1905.

Definition in Terms of Order Alone in the Linear Continuum and in WellOrdered Sets. Read (Chicago) Dec. 30, 1904. Transactions of the American Mathematical Society, vol. 6, No. 2, pp. 165-171 ; Apr., 1905.

Whiтe, H. S. Linear Systems of Curves on Algebraic Surfaces. Read Sept. 2-5, 1903. The Boston Colloquium Lectures on Mathematics, pp. 1-30; 1905.

Wilczynski, E. J. Invariants of a System of Linear Partial Differential Equations and the Theory of Congruences of Rays. Read (San Francisco ) Apr. 25, 1903. American Journal of Mathematics, vol. 26, No. 4, pp. 319-360 ; Oct., 1904.

- On Ruled Surfaces whose Flecnode Curve Intersects every Generator in two C'oincident Points. Read Dec. 29, 1903. Transactions of the American Mathematical Society, vol. 5, No. 4, pp. 438-446 ; Oct., 1904.

- General Theory of Curves on Ruled Surfaces. Read Apr. 30, 1904. Transactions of the American Mathematical Society, vol. 6, No. 1, pp. 7582 ; Jan., 1905.

- General Projective Theory of Space Curves. Read (San Francisco) Oct. 1, 1904. Transactions of the American Mathematical Society, vol. 6, No. 2, pp. 99-133 ; Apr., 1905.

Woons, F. S. Forms of Non-Euclidean Space. Read Sept. 2-5, 1903. The Boston Colloquium Lectures on Mathematics, pp. 31-74; 1905.

Wright, J. E. Application of the Theory of Continuous Groups to a Certain Differential Equation. Read Dec. 29, 1904. Bulletin of the American Mathematical Society, vol. 11, No. 4, pp. 180-182; Jan., 1905.

Young, J. W. On the Use of Hypercomplex Numbers in Certain Problems of the Modular Group. Read Sept. 17, 1904. Bulletin of the American Mathematical Socrety, vol. 11,.No. 7, pp. 363-367 ; Apr., 1905. 